\title{
Officials try to allay fears
}

\section{Washington}

Health agencies in the United States and Europe are trying hard to put to rest fears of a connection between the use of human insulin and the deaths of several insulindependent diabetics.

The issue, which has caused some alarm in British medical circles in recent weeks, is based upon an apparent increase in the number of deaths, due to "hypoglycaemic unawareness", in diabetics who have switched from animal-derived to human insulin.

Hypoglycaemia, or insulin reaction, strikes diabetics when the level of insulin in their blood is too high relative to their blood sugar level. The hypoglycaemic reaction is normally preceded by numerous physical symptoms such as hunger, sweating and poor coordination, and is reversed by consuming sugar. But anecdotal reports in Britain have suggested that in some diabetics who have switched from animal-derived to human insulin, the warning symptoms of a hypoglycaemic reaction are much less noticeable. This phenomenon has been linked to 17 deaths in Britain in the past year.

No scientifically established link exists between hypoglycaemic unawareness and use of human insulin, but enough concern has already been generated in Britain to have spurred further investigation. As in the United States, most of Britain's 200,000 diabetics have now switched from animal-derived to human insulin. Although some human insulin is manufactured by conversion from animal sources, much of it is synthesized using recombinant DNA technology, a fact that may well have inflamed the fears; human insulin is one of only a few genetically engineered products in wide use.

The UK Committee on the Safety of Medicines announced last month that with the help of the British Diabetic Association (BDA) it would investigate the reports of hypoglycaemic unawareness. In a recent UK survey, 6 per cent of 302 randomly selected diabetics reported diminished awareness of hypoglycaemia after switching from animal to human insulin. An earlier Swiss study, from 1987, reported diminished awareness in more than one-third of the 176 patients interviewed. Meanwhile, the BDA is said to have received some 60 unsolicited letters from patients complaining of hypoglycaemia with human insulin, sometimes with altered awareness.

With concern spreading overseas, the American Diabetes Association last week issued a statement urging people with diabetes "not to overreact". "There are no scientific studies confirming these initial reports", the statement stresses, adding that, given the complexity of mechanisms that warn the body of hypoglycaemia, it "is very unlikely to be due simply to the type of insulin used." Dr Robert E. Silverman, chief of the diabetes programme branch of the US National Institutes of Health (NIH), says that hypoglycaemic unawareness does not seem to be a problem in the United States. Silverman's group is sponsoring a comprehensive long-term clinical study of diabetes, involving some 1,400 diabetic subjects, and so far an increase in hypoglycaemic unawareness "hasn't jumped out of our data", although the issue is not a specific focus of the study.

Silverman is confident that if hypoglycaemic unawareness were a problem among US diabetics, indications would have shown up through the NIH study or in the adverse drug reaction programme sponsored by the US Food and Drug Administration. Although he does not dispute the UK findings, Silverman has reservations about them because they are based upon "retrospective reporting by patients of something that happened in the past". But he says that animal-derived and human insulin are known to have different kinetics of absorption into the bloodstream, and that close monitoring is merited when patients alter their treatment regimens.

Edward West, a spokesperson for Eli Lilly and Co., the largest manufacturer and distributor of human insulin in the United States, warns against what he calls "a great deal of misinterpretation" over the issue, and adds that none of the reported deaths have occurred in patients who were taking insulin manufactured by his company. Nevertheless, West says that his company already incorporated warnings about the potential for altered awareness of hypoglycaemia in its patient literature on human insulin. In response to a request by the British Licensing Authority, all insulin manufacturers in Britain are said to have made the change in their literature as well. Seth Shulman

\section{WEATHER FORECASTING}

\section{Monsoon prediction model}

\section{New Delhi}

ACCurate predictions of the behaviour of the Indian monsoon for the past two years have bestowed a new confidence on the scientists of the Indian Meteorological Department (IMD) and their new longrange forecasting model. Monsoon forecasts have great economic and even political value; the amount of rain that falls from June to September affects not only the agricultural success of large parts of the country but also, as a consequence, their political stability. Earlier efforts to predict monsoon behaviour have, however, been largely fruitless.

The IMD now claims it has a qualitative model good enough to be a useful tool in decision-making. Meterologists say they can predict, two months in advance, not only whether the monsoon will be good or bad but whether total rainfall will be more or less than the normal 88 centimetres. The model is a simplistic one, based on isolated and empirical discoveries of links between a number of regional and global meteorological and oceanic parameters and the monsoon circulation. Fifteen such parameters have been identified as having a historical relationship with monsoon rainfall. There seems to be a link, for example, between the strength of the El Niño phenomenon off the South American coast and the monsoon rainfall in the following year. And extensive Himalayan snow cover in winter, which increases albedo and leads to less continental heating, betokens a poor monsoon that summer.

From a study of monsoon rainfall between 1951 and 1987, IMD meteorologists argue that India has a normal monsoon whenever at least nine of the 15 parameters are favourable. By contrast, 1965 was a year of extreme drought and none of the parameters was favourable that year, whereas in 1955, which saw the heaviest monsoon of this century, only one parameter was unfavourable.

Despite the empirical nature of this model, Vasant Gowariker, secretary to the Department of Science and Technology, says IMD is "quite convinced" that a qualitative prediction of the monsoon can be made simply on the basis of how many of the 15 parameters are favourable. The model was first put to use in 1988 , when 13 of the 15 parameters indicated a good monsoon. In May that year, a month before the onset of the monsoon, IMD predicted a monsoon with total rainfall "on the positive side of normal"; the rainfall turned out to be 19 per cent above normal. The following year IMD predicted, this time two months in advance, another good monsoon and, at 30 September 1989, the total rainfall stood at 1.4 per cent above normal. Correct forecasts for two successive years, claims Gowariker, have "validated the utility of our model as a decision making tool". IMD scientists hope to derive quantitative predictions of the monsoon rainfall by weighting the 15 parameters differently. Like any statistical technique, Gowariker says, these models have limitations, "but they are the best available to make long-range forecasts of the monsoon."

K.S. Jayaraman 